\title{
(Sobre)vivências ribeirinhas na orla fluvial de Marabá- Pará: agentes, processos e espacialidades urbanas
}

\section{Riverine survivals in the riverside of Marabá city - Pará: agents, processes and urban spacialities}

Débora Aquino Nunes - Graduanda do curso de licenciatura e bacharelado em Geografia da Universidade Federal do Pará. Bolsista PIBIC/CNPq. E-mail: debora_aquino@hotmail.com

Saint-Clair Cordeiro Trindade Júnior - Doutor em Geografia Humana pela Universidade de São Paulo; Professor Associado III, do Núcleo de Altos Estudos Amazônicos da Universidade Federal do Pará e Bolsista Produtividade em Pesquisa do CNPq. E-mail: stclair@ufpa.br

\section{Resumo}

O presente trabalho aborda a relação cidade-rio na Amazônia, através de um estudo de caso: a orla fluvial da cidade de Marabá (sudeste do Pará). Objetiva analisar a dimensão do espaço vivido ribeirinho nessa cidade e sua relação com as ações do poder público materializadas em nível local. Por meio de pesquisa bibliográfica, documental e de campo (registro de histórias de vida, entrevistas semiestruturadas e observação sistemática), foi possível constatar que espaços de vivência ribeirinha no interior da cidade de Marabá coexistem com as novas tendências de apropriação de sua orla fluvial. Tal coexistência, entretanto, é, em grande parte, negligenciada pelas ações e intervenções do poder público que se voltam para o reordenamento desse espaço de contato imediato e de forte interação do homem citadino com o elemento hídrico.

\section{Palavras-chave}

Espaço vivido. Políticas Urbanas. Orla Fluvial. Marabá. Sudeste Paraense.

\section{Abstract}

This work is an approach of the cityriver relationship in the Amazon through a case study, the riverside of Marabá city (Southeast of Pará). The main objective is to analyze the importance of riverine living spaces in that city and their relationship to urban policies materialized at the local level. Through bibliographic, documental and field search (record life histories, semi-structured interviews and systematic observation), it was possible to find that riverine living spaces within Marabá city coexist with the new trends of riverside appropriation. This reality is often neglected by the action and intervention of public power which turn to the ordering of this space that have a strong relationship of the citizens with the water element.

\section{Keywords}

Lived Space. Urban Policies. Riverside. Marabá. Southeast Paraense. 


\section{INTRODUÇÃO}

A importância histórica de grandes rios, baías e igarapés para o início do povoamento da Amazônia é algo incontestável, já que foi por meio deles que se desenvolveu a circulação e o comércio de mercadorias extraídas, produzidas e consumidas na região (TRINDADE JR.; SANTOS; RAVENA, 2005). Assim, compreender a relação cidade-rio, em face das mudanças e permanências e frente aos diversos processos de exploração e inserção da Amazônia brasileira na economia nacional e internacional, consiste em uma análise fundamental para entendermos as diferentes formas como se manifesta o fenômeno urbano na região (LIMA, 2010).

A partir das novas redes de circulação implantadas na Amazônia Oriental, a cidade média de Marabá assumiu um papel fundamental para que o processo de expansão da fronteira econômica tomasse forma no sudeste Paraense, ratificando sua condição de centro sub-regional (TRINDADE JR. et al., 2011). O rio Tocantins foi fundamental na formação desta sub-região e da cidade de Marabá, mas teve seu papel econômico relativizado em face das novas estratégias de ordenamento territorial, ou seja, o transporte rodoviário assumiu um importante papel na reestruturação do território amazônico, em detrimento do hidroviário. Porém, observa-se que este processo de negação do rio não é único e nem produz exclusivamente a compreensão do que seja hoje a cidade de Marabá, uma das principais cidades da Amazônia Oriental, pois espacialidades e temporalidades marcadas pelas fortes relações dos homens com o rio e com a natureza brotam no meio das fissuras da cidade, desenhando relações de vivência e sobrevivência em espaços como os da orla fluvial da cidade. Tratamse de espaços que escapam à imposição uniforme da lógica urbana capitalista e configuram-se como resistências e possibilidades que devem ser levadas em conta ao se pensar políticas públicas para a cidade de Marabá, e mesmo da Amazônia como um todo.

Neste trabalho, procuraremos discutir a relação cidade-rio a partir de uma fração do espaço urbano regional, a orla fluvial da cidade de Marabá-PA, e seus espaços de vivência ribeirinha ${ }^{1}$, que demarcam, cotidianamente, espacialidades e temporalidades diversas. O objetivo central é analisar a dimensão do espaço

\footnotetext{
Para efeitos da presente análise, estamos considerando espaços de vivências ribeirinhas aquelas realidades sociogeográficas onde se manifestam fortes relações de permanência da interação, de natureza multidimensional, entre populações citadinas com os rios, à margem dos quais as cidades se localizam. Nesse caso, fala-se de vivências relacionadas às práticas socioculturais locais e de estratégias de sobrevivência, associadas às práticas econômicas alternativas e de pequena escala (SILVA; MALHEIRO, 2005).
} 
vivido e sua relação com as políticas urbanas materializadas em nível local, em uma cidade originariamente ribeirinha e de nível intermediário na rede urbana da Amazônia Oriental.

Por que estudar os espaços de orla fluvial de uma cidade como Marabá? Na cidade em referência, mesmo que se faça presente o domínio de uma "psicosfera urbana" - esfera dos valores, dos comportamentos, que assume uma dimensão essencialmente urbana (SANTOS, 1994) -, não há como desconsiderar as fortes ligações presentes na orla com a vida ribeirinha tradicional. Assim, considerar o papel dessa cidade na nova dinâmica regional pressupõe a compreensão de conteúdos socioespaciais diversos, relacionados ao processo de urbanização que caracteriza o espaço amazônico, inseridos que estão em um ritmo de crescimento econômico intenso e marcados por processos de exclusão e de segregação, associados à expansão da fronteira urbana. Esse processo de urbanização que aí se manifesta não se resume, conforme demonstra Becker (1990), à simples proliferação e crescimento das cidades, mas difunde um novo modo de vida e uma nova lógica de ordenamento espacial, que passa a coexistir com as antigas relações e morfologias, materiais e sociais, que produziram e dinamizam cidades como Marabá. Os espaços de fortes relações da cidade com o rio aí existentes se configuram como uma das expressões dessa urbanização multifacetada, que merece ser entendida e, igualmente, considerada nas políticas urbanas.

Para efeito de argumentação, dividiremos nossa discussão em cinco sessões. Primeiramente, apresentaremos as principais reflexões sobre os aportes teóricos para o estudo da relação cidade-rio na Amazônia. Nesse item, encontrase sistematizada a revisão bibliográfica que sustenta a análise e as reflexões propostas. Tal sistematização será o ponto de partida para a segunda parte, que, sob a perspectiva da geografia histórica, servirá para contextualizar a nossa área de estudo, a orla fluvial de Marabá. A terceira parte é voltada para a análise da relação cidade-rio com base nos agentes, usos e processos socioespaciais presentes na orla fluvial de Marabá para, em seguida, no quarto momento, reconhecermos os espaços de vivência ribeirinha nessa mesma cidade, de forma a sinalizar para as vivências e experiências dos sujeitos presentes nesses espaços. Por fim, na quinta parte, faremos algumas considerações sobre as intervenções urbanas voltadas para a orla fluvial da cidade e a relação das mesmas com os espaços de vivência ribeirinha previamente identificados.

A linha teórica que dá base a essa argumentação está assentada na teoria da produção social do espaço e leva em conta o percurso metodológico regressivoprogressivo, que, segundo Lefèbvre (2002, 2008), permite-nos compreender a dinâmica social e sua espacialidade historicamente contextualizadas. É neste 
sentido que um duplo movimento se impõe ao conhecimento - o regressivo, que é, ao mesmo tempo, histórico-genético, haja vista sua imersão do momento atual ao passado; e o progressivo, que navega em sentido contrário e que apresenta as possibilidades do fenômeno investigado a partir de suas possíveis projeções futuras. Esse movimento de ir e vir, considerando as temporalidades e as espacialidades urbanas em diferentes contextos históricos, revela a complexidade do objeto de análise, sugerindo uma abordagem mais rica e profunda.

Com base nessa perspectiva, trabalhou-se com um estudo de caso, a cidade de Marabá, que é fortemente representativa de uma sub-região, o sudeste Paraense, na Amazônia oriental, onde o processo migratório e os investimentos públicos e privados foram decisivos para a sua configuração territorial atual. Nesse sentido, a análise leva em conta as repercussões diferenciadas dos processos recentes relacionados ao ordenamento territorial regional, buscando desvelar especificidades que possam estimular proposições de políticas de desenvolvimento regional e urbano mais próximas das particularidades sub-regionais. Isto porque, mesmo se verificando o domínio do urbano como modo de vida na Amazônia, não se pode desconsiderar a forte ligação material e imaterial da cidade com o rio, que alguns fragmentos do espaço urbano de Marabá apresentam, chamados aqui de espaços de (sobre) vivência ribeirinha (SILVA; MALHEIRO, 2005).

\section{APORTES TEÓRICOS PARA O ESTUDO DA RELAÇÃO CIDADE-RIO NA AMAZÔNIA}

Nesta análise, cidade e urbano são tomados como noções diferenciadas, ainda que muitas vezes indissociáveis. Aquela é compreendida enquanto dimensão material da sociedade, configurando-se como realidade aparente, imediata, um dado prático sensível e arquitetônico. Ela está em constante devir, situando-se como mediação entre duas ordens, a próxima ${ }^{2}$ e a distante ${ }^{3}$, lócus da produção e reprodução da vida, do valor de uso e do valor de troca, permeada de encontros e de desencontros (LEFEBVRE, 2001).

2 A ordem próxima se caracteriza pelas relações imediatas, relações diretas entre as pessoas e grupos que compõem a sociedade; grupos estes mais ou menos amplos, mais ou menos organizados e estruturados (LEFEBVRE, 2001).

3 A ordem distante é a ordem da sociedade, regida por grandes e poderosas instituições (Igreja, Estado), por um código jurídico formalizado ou não, por uma "cultura" e por conjuntos significantes. Institui-se em um nível superior, isto é, em um nível dotado de poderes (LEFEBVRE, 2001). 
A cidade difere-se do urbano, tido, por sua vez, como realidade social composta de relações construídas, reconstruídas e em construção. Pressupõe, portanto, uma morfologia social e também um modo de vida. Ele não existe, todavia, se for descolado de uma morfologia material, que nos remete recorrentemente a uma dada forma espacial, a cidade, ainda que possa se manifestar para além dela. Em sua existência, associada à virtualidade e à possibilidade, a vida urbana, sinônimo de "sociedade urbana", ou simplesmente "o urbano", não pode dispensar essa base prático-sensível, configurada em uma forma espacial, que é a própria cidade (LEFEBVRE, 2001).

Nesse sentido, é a partir do jogo contraditório e articulado de contextos e processos diversos que se pode compreender o urbano e a cidade na Amazônia, atentando sempre para a complexidade e as possibilidades desse fenômeno na região. Daí falar-se de realidades urbanas plurais na região, a fim de identificarmos a diversidade territorial, que também é uma urbanodiversidade, para melhor evidenciarmos a complexidade da vida urbana, que nessa mesma região se faz presente, notadamente a partir da segunda metade do século XX.

Observa-se que a rede urbana da Amazônia, até a década de 1960, caracterizava-se por um padrão espacial predominantemente ribeirinho e dendrítico, onde o rio era a principal via de circulação, elemento influente na localização das cidades e nas relações materiais e imateriais que as constituíam (CORRÊEA, 1987). É nesse contexto que Marabá emerge como cidade ribeirinha. Sua formação socioespacial está ligada fortemente à relação cidade-rio, localizada na região do sudeste paraense, no encontro das águas dos rios Itacaiúnas e Tocantins.

Ressaltamos, desde já, que entendemos cidades ribeirinhas como aquelas que apresentam uma forte ligação não apenas material, mas também simbólica com os rios. Portanto, não se definem simplesmente por estarem localizadas às margens deste, mas principalmente por estabelecerem relações que apresentam um conteúdo sociogeográfico tributário das águas, fortemente ligado à dinâmica da natureza e a uma temporalidade cadenciada, que são traduzidas no seu modo de vida, na sua paisagem ${ }^{4}$ e nas suas inter-relações, de caráter: funcional (circulação, uso doméstico etc.), de subsistência material (recursos), lúdico (uso para entretenimento e lazer) e simbólico-cultural (fonte de representação e de imaginário social). Tais cidades, ipso facto, contêm e estão

4 A paisagem é o conjunto de formas geográficas, naturais ou não, que, num dado momento, exprimem as heranças que representam sucessivas relações definidas pela interação homem e natureza. Ela se dá como um conjunto de objetos reais-concretos que se mostram de maneira fenomênica aos nossos sentidos. Porém, considerada em si mesma, a paisagem é apenas abstração, uma vez que sua realidade é histórica e social (SANTOS, 2009). 
contidas em um mundo de relações historicamente definidas (TRINDADE JR.; SILVA; AMARAL, 2008).

Essa dinâmica das cidades ligadas predominantemente aos cursos fluviais e à floresta se deu de forma mais intensa até 1960. Após esse período, a região amazônica passou a se integrar mais estreitamente aos interesses nacionais e internacionais, que se situam em uma lógica de reprodução ampliada do capital e de seus valores urbanos. A industrialização brasileira e a abertura de rodovias são alguns elementos que possibilitaram a entrada de novos capitais e agentes na região apoiados pelas políticas estatais. Com isso, a riqueza da Amazônia foi redimensionada do uso da floresta como matéria-prima extrativista, para incluir também o uso do subsolo, do potencial hidrelétrico e da terra (CORRÊA, 1987).

Destacamos que não se deve reduzir a complexidade das cidades e da rede urbana da Amazônia a padrões espaciais e a periodizações (pré-1960 e pós-1960). No entanto, estas operações intelectuais não podem ser totalmente negligenciadas, pois, em muitos casos, indicam caminhos para a compreensão dessa realidade. Nesse sentido, temos que relativizar as temporalidades e as espacialidades que coexistem diferentemente dentro da complexidade urbana das cidades amazônicas.

O espaço é outro conceito importante nesta reflexão, pois, segundo Lefèbvre (2002, 2008), o mesmo, enquanto produto social, admite diversas estratégias, sendo meio e mediação, instrumento e intermediário das práticas sociais que são eminentemente dialéticas. Ele é mediato e imediato, contraditório e articulado, bem supremo dos que vivem bem ou mal, é fim e, ao mesmo tempo, meio, estando essencialmente ligado às relações (sociais) de produção. O espaço, socialmente produzido, carrega consigo as marcas de diferentes processos e contextos, assim como desenha virtualidades e possibilidades a partir de suas potencialidades do presente. Nesse sentido, é dentro de uma multiplicidade de relações historicamente definidas e possíveis que os espaços de vivência ribeirinha da cidade de Marabá se apresentam. Estes que, de forma dialética, carregam uma diversidade de práticas sociais ligadas a uma temporalidade lenta, com fortes heranças no passado, e marcada pela dinâmica do rio e da natureza, onde relações de natureza orgânica e horizontal (SANTOS, 2009), de sociabilidades próximas, por assim dizer, realizam-se cotidianamente.

Observa-se que no espaço vivido ribeirinho no interior das cidades, as necessidades desenham, muitas vezes, relações diversas de vivência e de sobrevivência da população das águas, em suas várias dimensões. Integrantes e integrados à totalidade, esses espaços brotam como espaços das diferenças. Estas que nascem e se estabelecem através de formas alternativas de vivência 
e de convivência urbana que não se reduzem ao previsível, ao identificável, ao classificável (NASSER; FUMAGALLI, 1996), em uma palavra, às relações reguladas e/ou padronizadas da vida moderna.

No caso específico deste estudo, é na faixa de orla fluvial de Marabá que se condensam os espaços de vivência ribeirinha. A orla, segundo Trindade Jr., Santos e Ravena (2005), diz respeito ao espaço imediato de interação entre terra e água, configurando-se como um sistema de objetos espaciais/geográficos articulados por um sistema de ações históricas/culturais, cuja dinâmica está, em grande parte, relacionada a um certo grau de dependência entre terra e água e onde morfologia material e morfologia social se entrecruzam. Na orla é que se estabelece, em geral, um contato/dependência, material e/ou simbólico, mais intenso em relação aos cursos fluviais.

Neste sentido, entendemos que, na perspectiva do direito à cidade, conforme propôs Lefèbvre (2001), é possível discutir os espaços de vivência ribeirinha na orla fluvial de Marabá. Trata-se, nesse caso, de direito de todos, permeado pela produção e reprodução de relações sociais muito específicas. Esse direito pode também ser formulado como direito à vida urbana, transformada e renovada. E, como direito à diferença, não pode ser reduzido a práticas de simples retorno, visita ou de contemplação do rio, como se tem visto em grande parte das ações do poder público voltadas para as cidades ribeirinhas amazônicas. Assim, deve-se prevalecer o urbano como lugar de encontro, de prioridade, de valor de uso e inscrição no espaço de um tempo e de temporalidades que devem ser promovidas à posição de um supremo usufruto, desenhado na sua base morfológica prático-sensível da cidade enquanto forma urbanística (LEFEBVRE, 2001).

É nessa perspectiva que se busca pensar os espaços de forte interação cidade-rio, tendo em vista que é pela reprodução das relações sociais e materialidades espaciais, que as singularidades e particularidades da vida cotidiana se contrapõem à homogeneidade de valores tidos como globais. Com isso, manifestam resistências e possibilidades de uma nova urbanidade, que também pode ser construída com base em diferenças, registradas na vida cotidiana mais espontânea. Emergem, com isso, novas relações, novas sociabilidades e novas espacialidades, sinônimas de criatividade e de "obra", que nos remetem a pensar um direito à cidade, também em uma cidade amazônica, que seja pautado em valores de usos e em sociabilidades projetadas a partir de interações que colocam o rio como mediação de práticas econômicas, de mobilidade, de manifestações lúdicas e de representações simbólico-culturais. 


\section{DO BURGO DO ITACAIÚNAS À CIDADE MULTIFACETADA DE MARABÁ}

Como enfatizado anteriormente, o espaço, enquanto produto social, está em constante devir, sendo meio e mediação, produto e produtor de uma sociedade complexa; esta que não pode ser entendida dentro de um tempo retilíneo e estático, mas sim através de uma perspectiva histórico-geográfica de movimento, associada às diversas temporalidades e relações sociais.

O período do "boom" econômico da borracha na Amazônia (de 1850 a 1920) levou à expansão e consolidação de uma rede urbana dendrítica e ribeirinha e ao desenvolvimento de novos núcleos urbanos na região através das frentes de expansão que adentraram os principais rios da região. As gêneses de varias localidades foram influenciadas pelo novo papel que a Amazônia assumiu perante a divisão internacional do trabalho (CORRÊA, 1987). A criação da colônia agrícola do burgo do Itacaiúnas, em 1894, localizada a 8 quilômetros da foz do rio Itacaiúnas, originou-se dentro dessa conjuntura, através de uma expedição à procura de novas terras produtivas organizada por Carlos Gomes Leitão (EMMI, 1999).

O burgo de Itacaiúnas concentrava sua força de trabalho em atividades ligadas à agricultura, ao extrativismo da castanha-do-pará, à criação de gado e de outros animais (VELHO, 1972). Porém, com a descoberta dos campos de caucho, uma das matérias primas para a produção de borracha, o burgo passa a ter como atividade principal o extrativismo desse produto, mudando a sua localização para o pontal de terra formado na confluência dos rios Tocantins e Itacaiúnas, devido ser esse um local estratégico para o escoamento da produção e a comercialização do caucho. Desta forma, Marabá se insere no circuito da produção da borracha, baseada no capital mercantil e no sistema de aviamento (VELHO, 1972; DIAS, 1958).

Nesse contexto, essa cidade passou a ser importante nó articulador de sua hinterlândia imediata que, em 1913, através da lei estadual n 1278 , desmembrouse do município de São João do Araguaia e transformou-se em município do estado do Pará (EMMI, 1999). O caucho foi a base econômica de Marabá até a década de 1920, período em que começou a se consolidar a "crise da borracha", que assolou a região amazônica até a década de 1960. Essa crise levou Marabá a reorganizar sua produção e comércio e um novo produto se expandiu no mercado em meio às dificuldades, a castanha-do-pará, que dinamizou economicamente e demograficamente essa cidade, proporcionando a formação de uma oligarquia 
local, apoiada na atividade extrativista. Pela relevância que ganhou em meio à produção da castanha-do-pará e à crise da borracha, Marabá é elevada, em 1923, à categoria de cidade (VELHO, 1972).

A população, por volta do final da década de 1930, começou a se fixar cada vez na área urbana de Marabá, que se concentrava na margem esquerda do rio Tocantins (MARABÁ, 2008), principalmente porque se manifestavam, de forma modesta, as atividades mineradoras ligadas à extração de cristal de rocha e de diamantes (EMMI, 1999; VELHO, 1972). Assim, a cidade de Marabá continuava crescendo acompanhando o rio Tocantins, chegando a alcançar, por volta da década de 1950, a fazenda Santa Rosa, nas margens desse rio (DIAS, 1972); fato este que confirma a importância do espaço de orla fluvial para a expansão da cidade de Marabá.

A terra e a pecuária moderna ganharam, na década de 1950, cada vez mais importância, face às dinâmicas produtivas e socioespaciais do município de Marabá. Esse fato foi um dos responsáveis por ocasionar a quebra do poder oligopolista dominante, pois o controle da produção, a partir daquele momento, passava a ter mais relevância que o controle mercantil, uma das principais marcas da oligarquia marabaense (VELHO, 1972).

A cidade de Marabá, até 1963, concentrava-se na faixa da orla fluvial. A sua mancha urbana se estendia desde o pontal até o lote da rampa, na margem esquerda do rio Tocantins. Na margem direita desse mesmo rio localizava-se a comunidade do Geladinho. Porém, em 1964, com a abertura da rodovia PA-70, importante via terrestre que ligava Marabá ao restante do país, essa comunidade se dividiu, formando dois aglomerados, o Geladinho e o São Félix. Este último surgiu acompanhando a rodovia e o rio Tocantins (MARABÁ, 2006), indicando uma sensível reorientação do processo de ocupação nos arredores da cidade, que veio a ser reforçar em década posterior, com a construção da ponte sobre o mesmo rio.

Em 1974 surge o núcleo urbano planejado pela Superintendência do Desenvolvimento da Amazônia (SUDAM), chamado Nova Marabá ${ }^{\text {. A }}$ implantação desse novo núcleo tinha como objetivo abrigar as pessoas que eram afetadas anualmente pelas enchentes na Marabá Pioneira, ou Velha Marabá. Porém, o projeto não obteve o efeito esperado, pois grande parte da população preferiu continuar morando naquele espaço do qual deveriam ser remanejadas (MARABÁ, 2006). Nesse período a cidade de Marabá começou a crescer

\footnotetext{
Hoje, Marabá é composta oficialmente por cinco núcleos urbanos: Marabá Pioneira, onde a cidade nasceu; Nova Marabá, núcleo planejado pela SUDAM; Cidade Nova, São Félix e Morada Nova, áreas de forte expansão urbana, que obedecem lógicas mais espontâneas de crescimento (MARABÁ, 2006).
} 
acompanhando outras referências topológicas e sugerindo novas dinâmicas socioespaciais, desta feita, ligadas principalmente ao tempo rápido e à estrada.

A década de 1980 marcou grandes mudanças na dinâmica da cidade, pois é nesse período que se pode observar a exploração intensa de ouro em Serra Pelada, e que contribuiu para o novo dinamismo local. Este fato ocasionou um aumento considerável da circulação de pessoas e capitais em Marabá, pois a mesma exerceu um importante papel de entreposto comercial e de serviços associados à compra e a venda do ouro (MARABÁ, 2008).

A partir de 1990 se dá a formação do bairro Santa Rita, área de ocupação mais recente da orla do Tocantins (LIMA, 2010). No início da década de 2000, uma parte da orla da cidade de Marabá - início do bairro Francisco Coelho, bairro Centro e Santa Rita - foi alvo de obras de infraestrutura portuária, tornando-se áreas atrativas, pela vista que oferecem do rio e pela concentração de equipamentos urbanos ligados ao entretenimento e ao lazer, principalmente no bairro Centro (MARABÁ, 2006).

O crescimento econômico e espacial da cidade de Marabá tem conduzido à definição de novas formas de apropriação e uso do solo urbano na sua orla fluvial; fato que repercute na definição de espacialidades e territorialidades conflituosas (LIMA, 2010). Neste sentido, entendemos que a relação cidaderio em Marabá sofreu significativas alterações nas últimas décadas, sobretudo após a entrada mais efetiva de capitais nacionais e internacionais, que foram incentivados através de políticas do Estado. Tais políticas carregam consigo um ideal de modernidade, onde o tempo rápido, a racionalidade mercadológica, as relações verticais e de consumo se impõem, construindo uma nova cidade com novos valores. É importante ressaltar, entretanto, que na orla fluvial de Marabá a lógica de produção do espaço, associada ao tempo lento do rio ainda persiste, o que implica em dizer que as duas dinâmicas aqui mencionadas coexistem em um mesmo espaço, através de temporalidades e espacialidades que se justapõem e que se tensionam.

\section{A RELAÇÃO CIDADE-RIO: AGENTES, USOS E PROCESSOS SOCIOESPACIAIS PRESENTES NA ORLA FLUVIAL DE MARABÁ}

A interação da cidade com o rio na orla fluvial de Marabá apresenta cotidianamente uma diversidade de usos, agentes e processos, que se relacionam dialeticamente. Os rios Tocantins e Itacaiúnas, que banham Marabá, têm seus 
usos relacionados, principalmente, à obtenção de recursos, como o peixe e a água, sendo que esta última é utilizada também para beber, tomar banho e lavar a roupa e a louça.

Outras formas de uso bastante significativas dos rios é o lazer e a contemplação da paisagem (LIMA, 2010). Segundo Lima (2010), estes tendem a ser seus principais usos, que se fazem presentes de forma significativa através de práticas como: os banhos nos rios, as caminhadas de fim de tarde, a contemplação e o entretenimento proporcionado pelas casas de show, boates, bares etc.

Na orla fluvial da cidade de Marabá, com base em Corrêa (1993) e Santos (2008), pode-se encontrar os seguintes agentes produtores do espaço: proprietários dos meios de produção/comércio/serviços, proprietários fundiários, Estado, grupos sociais excluídos e agentes do circuito inferior da economia. Não foi observada a presença dos promotores imobiliários ${ }^{6}$, de que trata Corrêa (1993).

São proprietários dos meios de produção/comércio/serviços os grandes industriais e comerciantes e prestadores de serviços, que em razão da dimensão de suas atividades, consomem amplos espaços, necessitando de vastos e baratos terrenos que satisfaçam aos seus requisitos locacionais e estejam próximos a locais de fácil acessibilidade (CORRÊEA, 1993). Assim, os proprietários dos meios de produção/comércio/serviços que se concentram na orla de Marabá estão localizados principalmente nos bairros Centro e Santa Rosa. Segundo Lima (2010), são nesses espaços que se encontram mais intensamente os comércios de maiores portes da orla (bares, boates, restaurantes, casas de show etc.). E interessante observar, também, na orla, a presença do setor industrial da Aços Laminados do Pará (ALPA), da Companhia Vale do Rio Doce, que sugere uma nova forma de apropriação da relação cidade-rio.

Identifica-se também, no espaço da orla, os proprietários fundiários, que segundo Corrêa (1993), são agentes interessados na especulação fundiária, no interesse maior do valor de troca da terra em detrimento do seu valor de uso. Eles são encontrados de forma mais visível no bairro Santa Rita, pois é marcante neste espaço a presença de terrenos cercados à espera da valorização por parte de seus proprietários (LIMA, 2010).

O Estado é um agente que atua em três níveis político-administrativos (federal, estadual e municipal) através de um conjunto de instrumentos institucionais, jurídicos e normativos, de regulação do uso do solo. A sua ação é complexa e diversificada, tanto no espaço como no tempo, pois é reflexo da

\footnotetext{
6 Os promotores imobiliários formam um conjunto de agentes que realizam, parcial ou totalmente, as seguintes operações: incorporação, financiamento, estudo técnico, construção e comercialização de imóveis (CORRÊA, 1993).
} 
dinâmica da sociedade da qual é parte constituinte (CORRÊEA, 1993). Observa-se que é relevante a sua ação na orla de Marabá, através de obras de infraestrutura, como a construção da estrada da Mangueira, no bairro Santa Rita; do calçadão e do cais de arrimo, na orla do rio Tocantins, que vão desde os limites dos bairros Francisco Coelho e Centro até o bairro Santa Rosa; das casas em construção pelo Programa de Aceleração do Crescimento (PAC), às margens do rio Itacaiúnas, no bairro Francisco Coelho; e parte do espaço da orla que abrange o antigo porto, que é ocupado pelo grupamento militar da Amazônia ( $8^{\mathrm{a}} \mathrm{RM}$ ).

Outros agentes importantes são os grupos sociais excluídos, que, segundo Corrêa (1993), são aqueles que enfrentam dificuldades de acesso a bens e serviços produzidos socialmente e tornam-se, efetivamente, agentes modeladores do espaço, ao se apropriarem, como forma de resistência e de sobrevivência, de terrenos públicos, privados e/ou áreas usualmente inadequadas para os outros agentes de produção do espaço. Na orla fluvial de Marabá, esses agentes se concentram na comunidade do Geladinho, no Porto das Canoinhas, no Lote da Rampa, nos bairros Francisco Coelho, Santa Rita, São Félix e Amapazinho. Dada a localização desses grupos sociais excluídos na orla e as condições de moradia a que estão submetidos, são agentes bastante vulneráveis, especialmente em decorrência das cheias a que estão sujeitas suas moradias, devido à elevação anual das águas dos rios Tocantins e Itacaiúnas.

$\mathrm{Na}$ orla identificamos também os agentes do circuito inferior da economia urbana, que são caracterizados por desempenharem atividades econômicas de pequenas dimensões, a exemplo dos ambulantes, dos artesãos, dos donos de estabelecimentos de pequenos comércios e serviços. Essas atividades são exercidas principalmente pelas populações pobres, abrigando os citadinos desprovidos de capital e de qualificação profissional (SANTOS, 2008). A presença desses agentes é flagrante em praticamente toda a orla fluvial de Marabá, onde se pode observar a concentração de pequenos bares que movimentam cotidianamente o Lote da Rampa e o bairro São Félix, e a presença relevante de pescadores e barqueiros concentrados no Porto das Canoinhas, no Amapazinho, nos bairros Centro e Santa Rosa. Nestes bairros, também encontramos a presença significante dos vendedores ambulantes e de pequenas indústrias de fabricação de gelo.

Além dos agentes, foi possível identificar também alguns processos socioespaciais responsáveis pela dinâmica urbana à beira-rio. Como responsáveis pela organização intraurbana do espaço da orla e pela divisão social e econômica do espaço, foram reconhecidos os seguintes processos espaciais: a centralização, a coesão, a segregação, a invasão-sucessão e a inércia, conforme a tipologia 
apresentada por Corrêa (1993). O processo de descentralização ${ }^{7}$ não foi identificado na orla fluvial de Marabá, pois não observamos concentração de comércios e serviços, formando sub-centros, fora da área central da orla. Os sub-centros existentes localizam-se em pontos relativamente distantes do espaço beira-rio.

O processo de centralização caracteriza-se pela formação da área central e é definido pela ação de sujeitos que promovem a concentração das principais atividades comerciais, de serviços, da gestão pública e privada, e os terminais de transportes inter-regionais e intraurbanos, gerando uma economia de aglomeração em determinado ponto ou setor do espaço urbano (CORRÊA, 1993).

Parte da orla fluvial de Marabá se configura como área central, pois concentra as atividades ligadas ao transporte fluvial, ao comércio, aos serviços e ao turismo, já que este espaço, notadamente nos bairros Centro e Santa Rosa, é o principal ponto de atividades econômicas e de serviços diversos e também de encontro e de lazer dos moradores e dos visitantes que chegam à cidade (MARABÁ, 2006).

Outro processo que podemos observar na orla é o de coesão, que se define como o movimento que leva as atividades semelhantes, distintas e/ou complementares a se localizarem juntas, gerando uma economia de aglomeração (CORRÊA, 1993). É principalmente nos bairros Centro e Santa Rosa que identificamos este processo, pois concentram as atividades ligadas ao comércio, ao entretenimento, ao lazer e às alternativas de alimentação, atraindo para si a população marabaense e os turistas.

O processo de segregação se caracteriza por ser a expressão e o resultado no espaço da distinção entre classes sociais, sendo verificado através do diferencial espacial de localização das moradias, vistas em termos de conforto e qualidade (CORRÊA, 1993). Na orla fluvial de Marabá observamos o processo de segregação presente em espaços como a comunidade do Geladinho, o Porto das Canoinhas, o Lote da Rampa e os bairros Santa Rita, Francisco Coelho, Amapazinho e São Félix. Esses espaços apresentam uma precariedade tanto no que diz respeito às condições de moradia, quanto aos serviços urbanos, como saúde, educação, segurança pública e infraestrutura; situação um tanto quanto

O processo de descentralização se caracteriza mediante a necessidade das empresas eliminarem as deseconomias geradas pela excessiva centralidade. A menor rigidez locacional no âmbito da cidade, em razão do surgimento de fatores de atração em áreas não centrais, do desenvolvimento do transporte rodoviário e aéreo (acessibilidade) e dos sistemas de comunicação, levam ao aparecimento de vários núcleos secundários de atividades fora da área central (CORRÊA, 1993). 
diferenciada do bairro Centro, onde se concentram as melhores moradias, os principais serviços e o comércio melhor estruturado da orla fluvial.

O processo de invasão-sucessão diz respeito a uma mutabilidade dinâmica da segregação. Por meio dele, por exemplo, um determinado setor habitado, durante um período de tempo, por um grupo social, passa a ser ocupado posteriormente por outro grupo, de status inferior ou superior ao grupo anterior (CORRÊA, 1993). Esse processo se intensificou na orla fluvial de Marabá, principalmente após a construção do calçadão e do cais de arrimo na porção central da orla. As obras realizadas fizeram com que esse espaço passasse por uma valorização, o que trouxe uma forte especulação imobiliária e o aumento do preço da terra, levando à substituição da população pobre, principalmente a que morava no bairro Centro, por grupos sociais de maior poder aquisitivo (MARABÁ, 2006).

O processo de inércia caracteriza-se através da força de permanência de determinados usos em certos locais da cidade, concorrendo para isso a preservação simultânea da forma e do conteúdo do espaço, apesar de terem cessado ou diminuído as causas que no passado justificaram a existência e localização deles (CORRÊA, 1993). Verificamos na orla de Marabá a presença desse processo através dos usos desse espaço e do rio para fins diversos, reafirmando a relevância do elemento hídrico para moradores e trabalhadores que situam suas experiências cotidianas nele ou a partir dele.

Esse processo é facilmente reconhecido em vários setores. Alguns aspectos da paisagem são reveladores da permanência de antigas formas espaciais e de seus respectivos conteúdos, como: presença de roupas estendidas nos varais; prática da pesca e/ou exposição de instrumentos relacionados a essa atividade próximos das moradias; banhos à beira-rio, mesmo com rede de abastecimento de água em casa; a presença de canoas, de rabetas ${ }^{8}$ e de outros tipos de pequenos barcos ao longo da orla; trapiches improvisados ou de rampas que dão acesso ao rio etc. Estas relações, dinâmicas e objetos permanecem, sendo formas-conteúdos que se fazem presentes significativamente nessa fração do urbano marabaense e que merecem um olhar mais atento.

8 Pequeno barco em madeira e movido a motor, muito utilizado na circulação regional, para o transporte de mercadorias e de pessoas. 


\section{VIVÊNCIAS E SOBREVIVÊNCIAS: PRODUÇÃO E REPRODUÇÃO DO ESPAÇO RIBEIRINHO MARABAENSE}

O encontro e o desencontro de diversas temporalidades e espacialidades se fazem presentes na orla de Marabá. Dentre essas relações, gostaríamos de nos deter um pouco mais naquelas que têm marcado a forte interação cidade-rio, em suas múltiplas dimensões, revelando um modo de vida ribeirinho inscrito na vida da cidade.

Para compreender a importância dos elementos desse modo de vida ribeirinho, levantamos, através de registros gravados, as histórias de vida ${ }^{9}$ de agentes que produzem e reproduzem cotidianamente esses espaços de diferença, presentes ainda nessa cidade do sudeste paraense sujeita a grandes mudanças. O Quadro 1 demonstra, de forma sistemática e sintética, fragmentos desses relatos que anunciam a natureza muldimensional do rio e da orla nas experiências pessoais dessa população.

Quadro 1: A relevância do rio e da orla para os agentes que produzem os espaços de vivência ribeirinha.

\begin{tabular}{|c|c|}
\hline $\begin{array}{l}\text { Importância do rio e } \\
\text { da orla }\end{array}$ & Excertos das narrativas \\
\hline Recurso & $\begin{array}{l}\text { "O meu modo de pescar é esse. Eu passo semana, } 15,20,30 \text {, } \\
\text { já passei até } 40 \text { dias sem vim pra casa, pescando. Só dentro } \\
\text { do rio [...], pesca de tarrafa, de malhadeira, de anzol, de arpão, } \\
\text { de tudo eu pesco. Aí, esse é meu modo de trabalhar, [...] sem } \\
\text { o rio eu não sei de que eu vou viver" (pescador } 1,40 \text { anos, } \\
\text { morador de Santa Rita). } \\
\text { "Eles botavam um arrastão. Arrastão é uma malhadeira que } \\
\text { eles põe aqui à beira do rio [...]. Aí fica lá em cima uma pessoa, } \\
\text { vigiando lá, quando aquele peixe entrava dentro daquele } \\
\text { círculo ele dava um sinal. Aí a turma vinha e pegava aqui a } \\
\text { ponta da rede, puxava assim, encostava na terra e os outros } \\
\text { vinham puxar" (pescador } 4,74 \text { anos, morador do Lote da } \\
\text { Rampa). } \\
\text { "Trabalhamos um pouco com tecidos, e depois nós } \\
\text { adaptamos o nosso ramo de negócio para o ponto. Que como } \\
\text { nós trabalhamos aqui na beira do rio, passamos a trabalhar } \\
\text { com artigos de caça e pesca, porque ficava mais próximo } \\
\text { aos pescadores" (comerciante } 1,63 \text { anos, morador do bairro } \\
\text { centro). }\end{array}$ \\
\hline
\end{tabular}

9 As histórias de vida foram coletadas junto aos moradores e comerciantes mais antigos dos espaços ribeirinhos vividos da cidade de Marabá-PA, em trabalho de campo realizado nos meses de outubro e de novembro de 2010. Foram coletados um total de dezenove relatos. 


\begin{tabular}{|c|c|}
\hline Circulação & $\begin{array}{l}\text { "Aqui tinha uns barcos tipo daqui acolá. Atravessava pra lá } \\
\text { pra trazer gente, a não ser aqueles que vinham na balsa, né? } \\
\text { Porque tinha balsa. Balsa grande que carregava } 3 \text {, } 4 \text { caminhão, } \\
\text { aí vinha gente também nela, mas atravessava mais era de } \\
\text { barco, o pessoal, né? [...] Hoje aí é pra atravessar gente lá pra } \\
\text { Ilha do Geladinho e aqui pra cima, que tem uma ilha. Mora } \\
\text { muita gente aí pra ilha. Pessoal tudo tem morada aí pra essas } \\
\text { ilhas. Ilha grande, naquelas torres [...] É, tem umas ilhas, e } \\
\text { eles trabalham pra lá, levando pr’ali” (pescador 7, 74 anos, } \\
\text { morador do Lote da Rampa) } \\
\text { "Nós trazia as mercadorias era de barco. A gente carregava } \\
\text { de Imperatriz e vem aí nos motor pra cá pra Marabá. Eu } \\
\text { não aguento ficar parado. Eu vou, ando de barco por aí, eu } \\
\text { carrego mercadoria de Imperatriz pra cá, que aqui tudo é } \\
\text { cachoeira. Eu conheço tudo aqui. A vida hoje balança, depois } \\
\text { que o cara fica velho. Mas tá bom, eu gosto, pra mim tá bom. } \\
\text { Hoje eu só faço pescar, viajo com esse pessoal aí de lancha. } \\
\text { Minha vida é essa, num fico parado dentro de casa não, que } \\
\text { adoece. No jeito que a gente vivia nossa vida, dentro dessas } \\
\text { matas aí, correndo com motor pra cima e pra baixo, aí, ficar } \\
\text { dentro de casa parado num aguenta não, dá uma depressão" } \\
\text { (pescador } 5 \text {, 66 anos, morador do bairro Francisco Coelho). } \\
\text { "Comecei a trabalhar na sobrevivência mesmo, pra manter a } \\
\text { família sendo 'freteiro' de barco nos rios, levando mantimento } \\
\text { praquelas fazendas. Inclusive, teve uma época que eu, na } \\
\text { exploração das Serras do Carajás, eu transportava o querosene } \\
\text { para os helicópteros. Quando foi pra explorar aquela Serra } \\
\text { dos Carajás não tinha estrada [...]. Pra ir pra Serra dos Carajás } \\
\text { levar esses mantimentos, essas coisas, ia de barco por esse } \\
\text { rio Itacaiúnas aí, 8, 10, } 12 \text { dias, puxando barco naquelas } \\
\text { cachoeiras. Corda, eixo, guincho, levando na costa, botando } \\
\text { pelo lá de cima pra passar o barco. Então, eu sobrevivi mais } \\
\text { assim, fazendo frete nesse rio Itacaiúnas, por isso que eu te } \\
\text { falo que ele é muito importante” (barqueiro e vendedor de açaí } \\
1,58 \text { anos, morador do bairro Francisco Coelho). }\end{array}$ \\
\hline
\end{tabular}




\begin{tabular}{|c|c|}
\hline Uso doméstico & $\begin{array}{l}\text { "Eu lavava roupa com a água do rio, buscava água do rio pra } \\
\text { beber, buscava água no rio pra lavar louça [...]. Ainda hoje eu } \\
\text { não tenho confiança em poço, e não tenho confiança nessas } \\
\text { águas, eu só tenho confiança mesmo nas águas que Deus } \\
\text { deixou, aquela ali, pra lavar roupa. Eu lavo louça, todo santo } \\
\text { dia. Vou de manhã, vou de tarde, meio dia eu vou, vou lavar a } \\
\text { louça do almoço, de manhã eu torno a juntar a louça do café } \\
\text { e tudo e desço de novo com a bacia cheia" (dona de casa 1, } \\
72 \text { anos, moradora do bairro Amapazinho). } \\
\text { "Hoje eu pego as roupas dos meus filhos e vou lavar tudinho, } \\
\text { aí eles botam dentro da bacia e eles levam. Chega lá eu meto } \\
\text { no sabão e lavo tudinho, aí eles vão trazer pra secar [...]. } \\
\text { Quando é aqui de verão, não adianta nem usar a máquina pra } \\
\text { lavar, lava tudo no rio, porque o poço seca" (dona de casa 7, } \\
72 \text { anos, moradora da comunidade do Geladinho). } \\
\text { "Aí eu saia de manhã mais minha mãe. Ia com minha mãe } \\
\text { pra água bater roupa [...]. Quando nós terminava daquilo } \\
\text { tudinho, aí nós botava nas lajes, que isso aí tudinho era só } \\
\text { pedra, estendia. Quando era negócio de duas horas, aquelas } \\
\text { que tava bem enxuta dobrava e trazia pra casa, aí as outras } \\
\text { nós fazia aquelas trouxas e botava na rua" (dona de casa } 7,72 \\
\text { anos, moradora da comunidade do Geladinho). }\end{array}$ \\
\hline Lúdico & $\begin{array}{l}\text { "Era muito peixe, chega dava gosto de ver tanto peixe. Era } \\
\text { aquela folia, aquela coisa, todo mundo alegre, uns gritavam, } \\
\text { uns riam, era animado, era divertido. Era pesado o serviço, } \\
\text { mas era divertido" (pescador } 4,74 \text { anos, morador do Lote } \\
\text { da Rampa). } \\
\text { "Quando a enchente vem, que chega numa casa ali, os outros } \\
\text { daqui: 'bora ajudar fulano!'. Ajuda. [...] vai montando na } \\
\text { praça, aquele horror de barraca [...]. Quando é a noite é aquele } \\
\text { festival, todo mundo na praça, aí que é animado mesmo. } \\
\text { Pessoal fica conversando, outro jogando baralho, outro } \\
\text { ouvindo som, bebendo, aí fica a noite todinha" (pescador } 3 \text {, } \\
65 \text { anos, morador do bairro Francisco Coelho). } \\
\text { "No inverno aqui é bom demais, porque quando toma ali, } \\
\text { até o trânsito para, de carro. Aí só fica mesmo os vizinhos. } \\
\text { A gente entra aqui, fica na porta da rua, não vê... só algum } \\
\text { barquinho por aqui que vê. É dos morador mesmo. Você vai } \\
\text { pra casa do vizinho até tarde conversar" (dona de casa } 7,72 \\
\text { anos, moradora da comunidade do Geladinho). }\end{array}$ \\
\hline
\end{tabular}




\begin{tabular}{|l|l|}
\hline Simbólico-cultural & $\begin{array}{l}\text { "Eu ia viajando à noite, escuro, no rio é escuro... Rapaz, era } \\
\text { eu que ia pilotando, foi quando a embarcação, pó-pó-pó fazia, } \\
\text { e quando uóó, uóó, balançou. Tava com } 60 \text { toneladas, toda } \\
\text { aquela castanha. Aí tem uma coisa que ninguém decifrou, } \\
\text { né? [...] Meu Deus do céu! Também não fiquei apavorado, só } \\
\text { cantou de novo, eu sai, será que foi esse buritizeiro? Cadê a } \\
\text { copa? Não vi a copa! Aí eu fui e pensei: deveria ter sido uma } \\
\text { cobra muito grande!” (ex-capitão de barco, 84 anos, morador } \\
\text { do bairro Centro). } \\
\text { "Pra mim o rio aqui é a coisa mais importante que eu achei } \\
\text { mesmo, é o movimento do rio, portanto que eu nasci e fui } \\
\text { criado aqui e não pretendo sair. É só porque se eu sair daqui } \\
\text { eu acho que eu vou pra longe do rio, né? Até tomar banho, o } \\
\text { dia que eu não venho tomar banho no rio eu acho ruim. Lá } \\
\text { em casa tem água, tem tudo, mas o meu movimento é no rio, } \\
\text { banhar, minha relação é essa" (pescador 3, 65 anos, morador } \\
\text { do bairro Francisco Coelho). } \\
\text { "Olha, devido eu morar desde criança, na margem desse rio, } \\
\text { o Tocantins, eu criei essa amizade muito grande com isso } \\
\text { aqui, e não pretendo sair daqui [...]. Gosto de estar na margem } \\
\text { desse rio, e gosto de ficar e conviver aqui com esse povo aqui } \\
\text { da minha cidade" (comerciante 1, 63 anos, morador do bairro } \\
\text { Centro). }\end{array}$ \\
\hline
\end{tabular}

Fonte: Elaborado por Débora Aquino Nunes com base nas histórias de vida narradas por ocasião do trabalho de campo (out. e nov. 2010).

Expressamos nesse quadro, a partir de fragmentos das trajetórias de vida dos agentes entrevistados, as experiências trazidas pelo tempo e as diferentes dimensões materiais e imateriais que permeiam cotidianamente a relação cidaderio nos espaços de vivência ribeirinha; estes que vivem e sobrevivem dentro do turbilhão fugaz e efêmero, cotidiano e duradouro, de ordens próximas e distantes a que está sujeita a cidade de Marabá, alçada nas últimas décadas à condição de cidade média e de grande importância para os novos processos e atividades econômicas que reconfiguraram geograficamente o sudeste paraense e a Amazônia Oriental.

Na narrativa desses sujeitos, a beira-rio não é apenas mais uma localização geográfica na cidade e o rio não é apenas um cenário a compor uma paisagem estática. Tanto um como outro estão intrinsecamente ligados à dinâmica da cidade, que não tem seus limites definidos pela linha d'água, mas adentra nela e, posteriormente, em sentido inverso, reelabora o viver urbano. É isso que os caracteriza como realidades eminentemente dinâmicas, não sendo, portanto, 
espaços isolados, ainda que as mudanças verificadas no sudeste paraense alterem também as relações e as estratégias ligadas à dinâmica e ao uso do rio e da natureza. Não obstante, revelam possibilidades e diferenças que se abrem, persistem ou se metamorfoseiam no modo de vida ribeirinho construído à beira do Tocantins e do Itacaiúnas.

É nesse sentido que se faz relevante entender tais espaços como resíduos ${ }^{10}$, que, negado dentro da realidade contraditória, não desaparecem, persistindo em vários momentos da vida: no contato sensorial com as coisas, no uso ocultado pela troca, nos afetos e na dimensão cotidiana do que é vivido. É assim que a diferença, nesses espaços, nasce de movimentos que contêm tanto a repetição como a criação (NASSER; FUMAGALLI, 1996).

Ainda que, aparentemente, nessa cartografia urbana, figurem de maneira puntiforme, como se estivessem estilhaçados e distribuídos em forma de fragmentos resultantes de fortes impactos e de mudanças presentes na cidade, os principais espaços de vivência ribeirinha que identificamos não estão, todavia, confinados e restritos a pontos cartesianamente delimitados nessa geografia urbana de Marabá. Eles fazem parte de uma totalidade e criam recorrentemente permeabilidades socioespaciais, não se deixando negar no movimento que define a cidade e suas intenções, mesmo que isso se faça, não raro, de forma tensa e contraditória. São, por isso, verdadeiras mediações entre ordens próximas e ordens distantes que dão sentido ao urbano e à cidade na Amazônia.

A caracterização, as particularidades e as singularidades desses espaços são apresentadas sistematicamente e sinteticamente no Quadro 2. Nele, além da identificação desses fragmentos espaciais no contexto da orla e também da cidade em seu conjunto, são reconhecidos elementos que marcam a paisagem mesclada da cidade com o rio, assim como usos, funções e práticas socioespaciais recorrentes na vida urbana que se instala à beira-rio.

10 As diferenças que não sucumbem à equivalência conferida pelos processos de homogeneização, são, pois, resíduos, que é tudo aquilo que não se deixou capturar ou aprisionar em modelos reguladores. Por isso representam o novo, que emerge de um movimento dialético, de inclusão e exclusão, mas portadores de vida e de práticas marcadas pela diferença (NASSER; FUMAGALLI, 1996). 
Quadro 2: Espaços de vivência ribeirinha na orla dos rios Tocantins/Itacaiúnas (Marabá-PA).

\begin{tabular}{|c|c|c|c|}
\hline Espaço & Rio & $\begin{array}{c}\text { Principais elementos } \\
\text { identificadores da paisagem }\end{array}$ & Usos e funções \\
\hline $\begin{array}{c}\text { Bairro } \\
\text { Cabelo Seco }\end{array}$ & $\begin{array}{c}\text { Encontro } \\
\text { dos rios } \\
\text { Tocantins } \\
\text { e } \\
\text { Itacaiúnas }\end{array}$ & $\begin{array}{l}\text { Pequenas e modestas casas de madeira; } \\
\text { acesso de terra ao rio Tocantins e } \\
\text { Itacaiúnas; roupas estendidas em } \\
\text { varais nas ruas, nas varandas ou } \\
\text { em cima dos telhados das casas; } \\
\text { canoas e rabetas à beira-rio; cadeiras } \\
\text { em frente das casas ao entardecer; } \\
\text { moradores tomando banho de rio ou } \\
\text { conversando em frente às moradias; } \\
\text { homens e mulheres com a pele } \\
\text { queimada de sol saindo ou chegando } \\
\text { da pesca. }\end{array}$ & $\begin{array}{l}\text { Moradia; uso } \\
\text { doméstico do } \\
\text { espaço da orla e } \\
\text { da água do rio; } \\
\text { atividade portuária } \\
\text { de pequena escala; } \\
\text { lazer no rio e na } \\
\text { orla. }\end{array}$ \\
\hline $\begin{array}{l}\text { Rampa da } \\
\text { Orla } \\
\text { Sebastião } \\
\text { Miranda }\end{array}$ & $\begin{array}{c}\text { Rio } \\
\text { Tocantins }\end{array}$ & $\begin{array}{l}\text { Rampa com acesso ao rio; tábuas de } \\
\text { madeira dentro do rio para lavagem } \\
\text { de roupas/louças; canoas, rabetas, } \\
\text { jet-skis e casas flutuantes aportadas } \\
\text { ao redor da rampa; homens, mulheres } \\
\text { e crianças tomando banho de rio; } \\
\text { equipamentos de lazer. }\end{array}$ & $\begin{array}{l}\text { Atividade portuária } \\
\text { de pequena escala; } \\
\text { lazer no rio e na } \\
\text { orla; uso doméstico } \\
\text { da água do rio. }\end{array}$ \\
\hline $\begin{array}{l}\text { Lote da } \\
\text { Rampa }\end{array}$ & $\begin{array}{c}\text { Rio } \\
\text { Tocantins }\end{array}$ & $\begin{array}{l}\text { Pequenas e modestas casas de madeira } \\
\text { ou alvenaria; rampa com acesso ao rio; } \\
\text { tábuas de madeira dentro do rio para } \\
\text { lavagem de roupas/louças; canoas } \\
\text { e rabetas justapostas e aportadas ao } \\
\text { redor da rampa; roupas estendidas } \\
\text { em varais; redes atadas nas varandas/ } \\
\text { salas das casas; cadeiras na frente das } \\
\text { casas; bares/restaurantes; pescadores } \\
\text { nas ruas e beira-rio; abrigos para as } \\
\text { canoas feitos de madeira e palha; } \\
\text { moradores tomando banho de rio. }\end{array}$ & $\begin{array}{l}\text { Moradia; atividade } \\
\text { portuária de pe- } \\
\text { quena escala; lazer } \\
\text { na orla e no rio; } \\
\text { uso doméstico do } \\
\text { espaço da orla e da } \\
\text { água do rio. }\end{array}$ \\
\hline $\begin{array}{l}\text { Porto das } \\
\text { Canoinhas }\end{array}$ & $\begin{array}{c}\text { Rio } \\
\text { Itacaiúnas }\end{array}$ & $\begin{array}{l}\text { Casas modestas de madeira, com } \\
\text { portas e janelas abertas para a rua; } \\
\text { acesso de terra ao rio Itacaiúnas; } \\
\text { tábuas de madeira dentro do rio } \\
\text { para lavagem de roupas/louças; } \\
\text { moradores tomando banho de rio; } \\
\text { redes estendidas nas salas/varandas } \\
\text { das casas; cadeiras em frente das } \\
\text { casas; canoas e rabetas aportadas à } \\
\text { beira-rio. }\end{array}$ & $\begin{array}{l}\text { Moradia; atividade } \\
\text { portuária de pe- } \\
\text { quena escala; lazer } \\
\text { na orla e no rio; uso } \\
\text { doméstico da orla e } \\
\text { da água do rio. }\end{array}$ \\
\hline
\end{tabular}




\begin{tabular}{|c|c|c|c|}
\hline $\begin{array}{l}\text { Amapazi- } \\
\text { nho }\end{array}$ & $\begin{array}{c}\text { Rio } \\
\text { Itacaiúnas }\end{array}$ & $\begin{array}{l}\text { Canoas e rabetas aportadas à beira- } \\
\text { rio; acesso de terra ao rio Itacaiúnas; } \\
\text { casas modestas de alvenaria; } \\
\text { moradores conversando nas ruas e } \\
\text { em frentes das casas; homens saindo } \\
\text { ou chegando da pesca; homens, } \\
\text { mulheres e crianças tomando banho } \\
\text { de rio. }\end{array}$ & $\begin{array}{l}\text { Uso doméstico } \\
\text { da água do rio; } \\
\text { atividade portuária } \\
\text { de pequena escala; } \\
\text { moradia. }\end{array}$ \\
\hline $\begin{array}{c}\text { Espaço } \\
\text { Beira-Rio da } \\
\text { Transman- } \\
\text { gueira (Bairro } \\
\text { Santa Rita) }\end{array}$ & $\begin{array}{c}\text { Rio } \\
\text { Tocantins }\end{array}$ & $\begin{array}{l}\text { Tábuas de madeira dentro do } \\
\text { rio que servem para lavagem de } \\
\text { roupas/louças; acesso de terra ao } \\
\text { rio Tocantins; casas modestas em } \\
\text { alvenaria; moradores tomando banho } \\
\text { de rio. }\end{array}$ & $\begin{array}{l}\text { Uso doméstico } \\
\text { da água do rio; } \\
\text { moradia; lazer no } \\
\text { rio. }\end{array}$ \\
\hline $\begin{array}{c}\text { Rampa do } \\
\text { Bairro Santa } \\
\text { Rosa }\end{array}$ & $\begin{array}{c}\text { Rio } \\
\text { Tocantins }\end{array}$ & $\begin{array}{l}\text { Concentração de pessoas, canoas } \\
\text { e rabetas; rampa em alvenaria } \\
\text { de acesso ao rio; abrigos feitos } \\
\text { em madeira e palha para a ponte } \\
\text { também em madeira que conecta as } \\
\text { canoas à rampa; refrigeradores para } \\
\text { os pescados; carros e caminhões } \\
\text { estacionados; intenso fluxo de } \\
\text { pessoas; comercialização de pescado; } \\
\text { colônia de pescadores Z30 e fábrica } \\
\text { de gelo. }\end{array}$ & $\begin{array}{l}\text { Atividade comercial } \\
\text { de pescado e } \\
\text { gelo ligada ao } \\
\text { circuito inferior da } \\
\text { economia urbana; } \\
\text { lazer no rio; } \\
\text { atividade portuária } \\
\text { e pesqueira. }\end{array}$ \\
\hline $\begin{array}{l}\text { Comunidade } \\
\text { do Geladinho }\end{array}$ & $\begin{array}{c}\text { Rio } \\
\text { Tocantins }\end{array}$ & $\begin{array}{l}\text { Praia; canoas e rabetas justapostas; } \\
\text { acesso de terra ao rio Tocantins; } \\
\text { bares com mesas e cadeiras na praia; } \\
\text { abrigos feitos de madeira e palha para } \\
\text { canoas, barcos e utensílios pesqueiros } \\
\text { e domésticos; palafitas; movimento } \\
\text { de pescadores e moradores; tábuas } \\
\text { de madeira dentro do rio para } \\
\text { lavagem de roupas/louças; visitantes } \\
\text { e moradores tomando banho de rio. }\end{array}$ & $\begin{array}{l}\text { Moradia; lazer no rio } \\
\text { e na orla; atividades } \\
\text { portuárias de } \\
\text { pequena escala; } \\
\text { comércio de } \\
\text { bebidas e comidas; } \\
\text { uso doméstico da } \\
\text { água do rio. }\end{array}$ \\
\hline $\begin{array}{l}\text { Rampa do } \\
\text { São Felix }\end{array}$ & $\begin{array}{c}\text { Rio } \\
\text { Tocantins }\end{array}$ & $\begin{array}{l}\text { Palafitas; bares; rampa em alvenaria } \\
\text { com acesso ao rio; canoas e rabetas } \\
\text { aportadas de forma justaposta; } \\
\text { movimento de pescadores e } \\
\text { moradores; tábuas de madeira dentro } \\
\text { do rio para lavagem de roupas/ } \\
\text { louças; redes de pesca estendidas nas } \\
\text { varandas/frentes das casas; visitantes } \\
\text { e moradores tomando banho de rio. }\end{array}$ & $\begin{array}{l}\text { Moradia; lazer } \\
\text { no rio; atividades } \\
\text { portuárias r de } \\
\text { pequena escala; uso } \\
\text { doméstico da água } \\
\text { do rio. }\end{array}$ \\
\hline
\end{tabular}

Fonte: Elaborado por Débora Aquino Nunes, com base no trabalho de campo (out. e nov. 2010). 
A apropriação desses diversos espaços é caracterizada por sua natureza diferencial de apropriação e de uso. Faz-se importante dizer, entretanto, que não se tratam de espaços intocáveis. Eles produzem e reproduzem o espaço urbano de maneira particular e/ou singular, abrindo um leque de possibilidades e virtualidades, com base em necessidades que se inscrevem nos lugares, situando o rio como parte das dinâmicas que lhe são inerentes. É por isso que muitas das práticas assinaladas a partir desses espaços deixam registros de relações cotidianas na paisagem. Os agentes, por seu turno, não estão apenas à beira-rio, mas se situam e interagem com e a partir dele. Desenvolvem desde práticas e manifestações de atividades econômicas, de mobilidade e de subsistência - como a pesca, o transporte, o uso doméstico da água - até manifestações de natureza mais lúdica, de lazer, de entretenimento e de imaginário cultural -, como os banhos de rio, os encontros e relações de vizinhança, as festas, as lendas, as histórias e estórias dos indivíduos e dos grupos. Mais que a localização dos mesmos no espaço, o estar à beira-rio, sugere, igualmente, a imersão deles em microcosmos que pressupõem uma forma de lidar com a natureza e de acompanhar seus ritmos.

A produção da orla fluvial de Marabá é marcada por objetos e práticas sociais que caracterizam a essência da relação cidade-rio, mas que também se metamorfoseiam, definindo embates entre agentes e processos, que pressionam mudanças na paisagem, nos valores e nos significados a ela reservados, revelando tensões e implicações recíprocas entre a cidade (a morfologia material) e o urbano (a morfologia social).

\section{INTERVENÇÕES URBANAS NA ORLA FLUVIAL DA CIDADE DE MARABÁ}

No cotidiano da orla fluvial de Marabá foi possível observar, apesar da precariedade da infraestrutura existente nos espaços de vivência ribeirinha, a riqueza da vida cotidiana que nela se inscreve. Entendemos que é necessário pensar a cidade para todos, levando em consideração as diferenças que nela se manifestam, que, na Amazônia, têm várias expressões, sendo a relação cidade-rio apenas uma delas.

Foi essa razão, a preocupação com a urbanodiversidade existente, que nos fez indagar sobre a relação entre as práticas espaciais vividas na orla e aquelas outras concebidas nas diferentes esferas e estruturas ligadas à tomada de decisão. 
Levantamos, então, as ações do poder público voltadas para a orla fluvial de Marabá (Quadro 3), onde as obras e as intervenções urbanas nela presentes nos ajudam a entender como tem sido pensado e (re)desenhado esse espaço pelo poder público em suas diferentes esferas (municipal, estadual e federal).

Quadro 3: Marabá: principais obras recentemente desenvolvidas pelo poder público na beira-rio.

\begin{tabular}{|c|c|c|c|c|}
\hline Obra & Descrição da obra & $\begin{array}{c}\text { Principais } \\
\text { funções e usos }\end{array}$ & Iniciativa & $\begin{array}{c}\text { Ano de } \\
\text { conclusão }\end{array}$ \\
\hline $\begin{array}{c}\text { Orla } \\
\text { Sebastião } \\
\text { Miranda }\end{array}$ & $\begin{array}{l}\text { A estrutura da obra } \\
\text { está sustentada por } \\
\text { oito metros de estacas } \\
\text { cravadas em concreto, } \\
\text { avançando em direção ao } \\
\text { rio, pilares de altura média } \\
\text { de } 4,5 \text { metros e uma laje } \\
\text { de } 20 \text { centímetros de } \\
\text { espessura. O calçadão } \\
\text { possui } 2 \text { metros de } \\
\text { largura, trapiches, portos } \\
\text { e equipamentos urbanos } \\
\text { ligados principalmente } \\
\text { à contemplação da } \\
\text { paisagem e ao lazer } \\
\text { (CORREIOS DO } \\
\text { TOCANTINS, 2004). }\end{array}$ & $\begin{array}{l}\text { Práticas de } \\
\text { comércio e } \\
\text { serviço; lazer; } \\
\text { turismo; uso } \\
\text { do rio para } \\
\text { população que lá } \\
\text { reside através de } \\
\text { trapiches e portos; } \\
\text { contemplação do } \\
\text { rio; contenção das } \\
\text { enchentes e do } \\
\text { processo erosivo } \\
\text { provocado pelas } \\
\text { águas. }\end{array}$ & $\begin{array}{l}\text { Governo } \\
\text { Federal, } \\
\text { através do } \\
\text { Departamento } \\
\text { Nacional de } \\
\text { Infraestrutura } \\
\text { de Transporte } \\
\text { (DNIT), em } \\
\text { parceria com } \\
\text { o governo } \\
\text { municipal. }\end{array}$ & 2004 \\
\hline $\begin{array}{l}\text { Trans- } \\
\text { mangueira }\end{array}$ & $\begin{array}{l}\text { Aterramento e } \\
\text { pavimentação da } \\
\text { Transmangueira, criando } \\
\text { um novo eixo de ligação } \\
\text { entre a Nova Marabá e a } \\
\text { Marabá Pioneira. } \\
\end{array}$ & $\begin{array}{l}\text { Fluxo de pessoas } \\
\text { e mercadorias; } \\
\text { transporte. }\end{array}$ & $\begin{array}{c}\text { Governo } \\
\text { Federal, em } \\
\text { parceria com } \\
\text { o governo mu } \\
\text { nicipal. }\end{array}$ & 2007 \\
\hline $\begin{array}{l}\text { PAC "Cabelo } \\
\text { Seco" }\end{array}$ & $\begin{array}{l}\text { Prevê a construção de } \\
\text { um muro de contenção, } \\
\text { terraplanegem, drenagem } \\
\text { das águas pluviais, } \\
\text { regulamentação fundiária, } \\
\text { pavimentação com } \\
\text { revestimento em concreto } \\
\text { e a construção de } 80 \\
\text { unidades habitacionais } \\
\text { que sejam assistidas com } \\
\text { rede de água e esgoto } \\
\text { (MARABÁ, 2007). }\end{array}$ & $\begin{array}{l}\text { Moradia; } \\
\text { saneamento; } \\
\text { contenção/ } \\
\text { amenização das } \\
\text { enchentes; espaço } \\
\text { para geração de } \\
\text { renda, inclusão/ } \\
\text { valorização } \\
\text { cultural e lazer } \\
\text { (MARABÁ, 2007). }\end{array}$ & $\begin{array}{c}\text { Governo } \\
\text { Federal, através } \\
\text { do Programa de } \\
\text { Aceleração do } \\
\text { Crescimento } \\
\text { (PAC), em } \\
\text { parceria com } \\
\text { o governo } \\
\text { estadual e } \\
\text { municipal. }\end{array}$ & $\begin{array}{c}\text { Em } \\
\text { andamen-to }\end{array}$ \\
\hline
\end{tabular}

Fonte: Elaborado por Débora Aquino Nunes, com base em Jornal Correios do Tocantins, Prefeitura Municipal de Marabá e trabalho de campo (out. nov. 2010) 
Ainda que se possa observar a instalação de alguns equipamentos urbanos na beira-rio, que reforçaram a face ribeirinha da cidade - como os portos e os trapiches construídos ao longo da orla, que são muito utilizados pelos moradores que aportam seus barcos, descem para pescar, tomar banho, lavar louça e roupa no rio (LIMA, 2010), a construção do calçadão e do cais de arrimo trouxe consigo novas funcionalidades que estariam voltadas, predominantemente, para o lazer, o consumo e o turismo dos visitantes ou de uma população solvável em nível local. Em entrevistas realizadas com representantes de instituições públicas que atuam na orla, foi possível perceber o quanto essa fração do espaço marabaense assume importância estratégica no contexto de suas ações. Na maior parte das vezes, essa importância é atribuída ao grande potencial turístico e comercial que ela revela.

$\mathrm{Na}$ mesma forma, obras que poderiam ser bem interessantes para a qualidade de vida da população aí existente acabam por revelar problemas que impactam os espaços de vivência ribeirinha. A rodovia Transmangueira, por exemplo, que foi pensada como uma alternativa para ligar dois núcleos da cidade, a Nova Marabá com a Marabá Pioneira, de forma a facilitar o fluxo e o movimento intraurbano de sua população, devido à precariedade de sinalização, tem provocado recorrentes acidentes e atropelamentos para as pessoas que circulam por essa via à beira-rio, não obstante ter ajudado a conter as enchentes anuais que ocorrem durante o chamado inverno amazônico, pois, com a terraplanagem, essa via ficou mais alta que as casas do seu entorno, formando uma barreira que impede, por certo tempo, que a água alcance as moradias.

Dentre as obras que mais se aproximam da dinâmica dos espaços de vivência ribeirinha, destaca-se o projeto de melhoria urbana do bairro "Cabelo Seco" (Francisco Coelho), financiado pelo PAC. Refere-se, entre outras, às ações de melhoria habitacional, voltadas para redução das desigualdades sociais e o desenvolvimento econômico compatível com a preservação ambiental e cultural, mantendo o vínculo da população com o rio, com a vizinhança e com o trabalho (MARABÁ, 2007).

Mesmo observando que há um esforço do poder público em pensar a dimensão ribeirinha da cidade de Marabá, esse não é o foco principal das políticas públicas voltadas para orla. As intervenções estão muito mais ligadas à dimensão do turismo e do consumo desse espaço, pouco atentando, portanto, para os usos e práticas enraizadas e aí existentes há bastante tempo. A tendência de transfiguração de cidadãos em consumidores (SANTOS, 2007), associada à perspectiva que transforma o rio em moldura urbana, parece se fazer presente direta ou indiretamente na maior parte das ações constatadas. 
Essa postura do poder público pode ser verificada através do Quadro 4, onde foram reunidos alguns trechos das entrevistas gravadas realizadas junto a técnicos, planejadores e representantes do poder público ligados às políticas de planejamento e de gestão urbana da cidade de Marabá.

Quadro 4: A importância do rio e da orla na concepção dos representantes do poder público.

\begin{tabular}{|c|c|}
\hline $\begin{array}{c}\text { Tipo de } \\
\text { importância }\end{array}$ & Excertos de entrevistas \\
\hline $\begin{array}{c}\text { Contemplação/ } \\
\text { lazer/turismo }\end{array}$ & $\begin{array}{l}\text { "É uma área de lazer, de comércio e de uma beleza cênica indescritível } \\
\text { que tem um grande potencial de exploração para o desenvolvimento da } \\
\text { economia do município, sem dúvida nenhuma" (secretário municipal 1). } \\
\text { "A trafegabilidade das pessoas na orla, os momentos de lazer que a orla } \\
\text { proporciona através da visão do nascer e do pôr do sol, a própria água e o rio } \\
\text { que você vê de uma forma confortável, vem trazer muitos benefícios. Tem } \\
\text { espaços pra caminhadas, pra corridas, para o esporte. Então, foi feito um } \\
\text { trabalho assim, dentro daquele espaço, que pudesse acolher e dar satisfação } \\
\text { ao maior número de pessoas [...]. A orla é hoje um espaço muito visitado } \\
\text { pela população, principalmente pelos turistas" (secretário municipal 2). } \\
\text { "Essa importância é totalmente turística [...]. Nós já identificamos através } \\
\text { de um trabalho para a escolha do símbolo turístico que a orla ela é um } \\
\text { dos principais atrativos turísticos nosso. Ela é o nosso cartão postal, } \\
\text { mesmo porque, por a gestão ter feito a orla, ter criado aquele equipamento } \\
\text { todo, aquela beleza, a contemplação natural do rio ainda é um atrativo" } \\
\text { (secretário municipal 3). } \\
\text { "O que a gente identificou foi o seguinte: a pesca esportiva, por exemplo, } \\
\text { é um atrativo turístico. É um incremento para o turismo, mas aí já cai na } \\
\text { questão dos peixes que estão sendo depredados através da pesca predatória } \\
\text { e a gente não tem como trabalhar isso. Então, a gente precisa criar ações } \\
\text { pra primeiro sanar essa questão da pesca esportiva, que é para que a gente } \\
\text { possa trabalhar e melhorar especificamente para o turismo o transporte } \\
\text { fluvial" (secretário municipal 3) }\end{array}$ \\
\hline Transporte & $\begin{array}{l}\text { "Olha o rio é um meio de transporte [...]. Já implementamos as rampas, } \\
\text { as escadarias, que de fato tem possibilitado aos pescadores, aos usuários } \\
\text { e aos esportistas a terem acesso aos recursos hídricos e fazer o usufruto } \\
\text { não só do comércio, mas também do esporte nessa região.A gente } \\
\text { quer transformar o rio em um grande sistema integrado de transporte" } \\
\text { (secretário municipal 1). } \\
\text { "Temos transporte fluvial de passageiros para Itupiranga, para outros } \\
\text { municípios perto daqui, e também para as pessoas que são ribeirinhos } \\
\text { [...]. No projeto amplo da ALPA está incluso o transporte fluvial com uma } \\
\text { hidrovia. Também está previsto pra que essa hidrovia venha subindo pelos } \\
\text { municípios vizinhos de Marabá, principalmente São João do Araguaia, que } \\
\text { vai para o rumo de Imperatriz. Então está no projeto amplo, macro do } \\
\text { governo, com também recursos do PAC, de fazer com que o rio Tocantins } \\
\text { seja totalmente navegável. Navegável não só pra transportar os produtos } \\
\text { exportados, no caso o minério de ferro, mas sim também as pessoas. Então } \\
\text { vai ter também, num futuro próximo, essa parte do transporte fluvial de } \\
\text { pessoas, de passageiros" (secretário municipal 2). } \\
\text { "Quanto à utilização de transporte fluvial para ir pra outros locais, ainda } \\
\text { não temos uma identificação específica com relação a isso" (secretário } \\
\text { municipal 3). }\end{array}$ \\
\hline
\end{tabular}




\begin{tabular}{|c|c|}
\hline Comércio/ serviços & $\begin{array}{l}\text { "A gente está aí com vários parceiros da União. Têm empréstimos sendo } \\
\text { viabilizados, tem parcerias com a iniciativa privada para que a gente possa } \\
\text { não só implantar a infraestrutura, mas revitalizar o comércio, implantar } \\
\text { a infraestrutura de iluminação pública, instituir praças de comércio" } \\
\text { (secretário municipal 1). } \\
\text { "Portanto, a orla municipal e o rio, ainda como legado da ocupação } \\
\text { municipal, eles são importantes para as tradições, para os eventos culturais, } \\
\text { para fortalecer a economia, onde cada evento cultural gera renda para } \\
\text { aqueles ribeirinhos. Eles, ora são pescadores, ora eles são ambulantes. Eles } \\
\text { fazem o fortalecimento econômico através da venda de seus produtos para } \\
\text { o turista que chega. Agora, uma coisa é importante: a geração de emprego } \\
\text { e renda, com a hidrelétrica que querem implantar, é um fator de debate } \\
\text { entre a comunidade e os autores desse projeto. Esperamos nós que seja } \\
\text { decidido da maneira correta. Então, entendemos que a orla municipal e o } \\
\text { rio Tocantins não são apenas fontes de emprego e renda, ou geração de } \\
\text { emprego e renda através da pesca, dos rabeteiros e do turismo que gera } \\
\text { aquele espaço social, mas é uma forma de unir, juntar a cultura e essas } \\
\text { forças econômicas" (secretário municipal 4). } \\
\text { "A geração de emprego e renda aos arredores, com bares e restaurantes, } \\
\text { locais de entretenimento e lazer, é importante para o turismo. Pra cidade, } \\
\text { a orla, ela tem uma conotação especificamente turística" (secretário } \\
\text { municipal 3). }\end{array}$ \\
\hline $\begin{array}{l}\text { Contenção de } \\
\text { enchentes }\end{array}$ & $\begin{array}{l}\text { "Queremos também diminuir, com as estruturas existentes, essa questão } \\
\text { dos impactos com relação ao processo de enchentes que todo ano ocorrem } \\
\text { na nossa região. O fato é que encontramos na nossa gestão um município } \\
\text { que pouco investiu na questão [...]. A gente está tentando reconstruir isso, } \\
\text { tentando treinar pessoas, instituir sistema de informações integradas que } \\
\text { possam nos ajudar não só a controlar, mas também ter capacidade de } \\
\text { construir projetos, de construir soluções [...]. Queremos uma orla que não } \\
\text { só valorize o turismo, mas também que faça uma proteção às enchentes. } \\
\text { Isso aí a gente já tem projetos construídos e estamos captando esses } \\
\text { recursos para realizar a ação dessas obras" (secretário municipal 1). }\end{array}$ \\
\hline
\end{tabular}

Fonte: Elaborado por Débora Aquino Nunes, com base em entrevistas com secretários municipais da Prefeitura de Marabá, realizadas por Michel Lima, abr. 2010, e integrantes do arquivo de dados primários do Grupo e Estudos e Pesquisas Sobre Ordenamento Territorial e Urbanodiversidade na Amazônia (GEOURBAM).

Assim, tendo como referência a produção social do espaço urbano e o direito à cidade, parece haver um embate entre os espaços vividos presentes na orla fluvial da cidade e aqueles que são concebidos ao nível das esferas responsáveis pelo planejamento e pela gestão urbana. A muldimensionalidade que caracteriza a relação da cidade com o rio na Amazônia tem sido pouco considerada, ou mesmo gradativamente subtraída nas políticas que se voltam para os espaços beira-rio.

Nessas cidades, onde o elemento hídrico se faz presente, a relação dos citadinos com o rio não se reduz à contemplação e ao lazer. Trata-se de uma relação que sinaliza, mesmo que de forma residual, para outras possibilidades 
de vida urbana, que envolvem práticas econômicas e culturais com fortes laços e enraizamentos que se articulam às dinâmicas e aos ritmos de uma natureza ainda presente na vida urbana. Olhar para esses espaços sem vê-los em suas múltiplas dimensões e interações, sugere desconsiderar verdadeiras resistências às tendências de homogeneização e estandardização das cidades, que parecem ser as principais marcas das políticas urbanas em curso.

\section{CONSIDERAÇÕES FINAIS}

Ao analisarmos a orla fluvial da cidade de Marabá, almejamos destacar a existência de espaços de vivência ribeirinha como marcas ainda presentes da paisagem e da dinâmica urbana. Tais espaços, caracterizados por uma forte ligação com o rio e com a natureza, por uma temporalidade lenta e por relações orgânicas e horizontais, passaram a coexistir, dentro de um movimento dialético, com as novas tendências de apropriação da orla, voltadas, principalmente, para o lazer e o turismo, onde o tempo veloz, o valor de troca e as relações verticais predominam.

Os espaços de vivência ribeirinha nos remetem a um jogo dialético de espacialidades e temporalidades diversas de uma sociedade que não é homogênea, onde as diferenças se encontram e se desencontram. Assim, entender e pensar o espaço vivido ribeirinho como um livro escrito com palavras difusas e complexas, contraditórias e articuladas, é refletir sobre o direito à diferença e à criação, indo além da mera repetição a que estão sujeitas as cidades, mesmo aquelas fortemente particularizadas por paisagens e práticas sociais muito específicas e singulares.

Ao adentrarmos nos espaços de vivência ribeirinha marabaense, verificamos que os serviços, como o de saneamento e o de abastecimento de água, aí não chegam, ou quando chegam, não são eficazes e eficientes. Percebemos, portanto, que esses espaços não são assistidos como deveriam ser pelo poder público, pois sofrem com a precariedade dos serviços e de infraestrutura. E isso se reflete nas marcas de vivência e sobrevivência e nas relações que são estabelecidas entre a cidade e o rio.

Destacamos, por isso, o fato de as políticas públicas desenvolvidas na orla de Marabá estarem mais voltadas para um tipo de comércio e serviço, para o estímulo ao consumo de populações solváveis e para o "embelezamento" paisagístico, com vistas à atratividade turística. Isso tudo em detrimento das intervenções urbanas necessárias, pelas quais os espaços vividos ribeirinhos muitas vezes gritam silenciosamente. 
Não entendemos que as demandas de fragmentos urbanos, como é o caso dos espaços de vivência urbana ribeirinha existentes em Marabá, sejam as principais ou únicas que devam ser levadas em consideração ao se pensar as políticas de intervenção urbana para aquela cidade. Porém, consideramos que esses mesmos espaços ribeirinhos ainda se fazem presentes com certa força na configuração urbana e desenham necessidades que devem ser reconhecidas pelo poder público, tanto quanto as novas demandas e funcionalidades que chegam com força inovadora.

É necessário, portanto, atentar para demandas que estão intimamente ligadas às interações que se estabelecem com o rio. Em outros termos, significa dar visibilidade a sujeitos pouco visíveis nas novas estratégias de produção do espaço. Por fim, entendemos que o sentido do valor de uso atribuído a práticas tidas muitas vezes como de menor importância, podem igualmente contribuir para outra interpretação do significado do urbano e da cidade e para redimensionar a busca do que seja realmente o direito à cidade na Amazônia. Esse direito não precisa necessariamente estar inspirado em parâmetros que igualem os indivíduos do ponto de vista dos valores urbanos de natureza etnocêntrica, mas pode muito bem estar assentado no potencial social de criação, de encontros, de tradições e de manifestações de práticas sociais e culturais diversas, capazes de sugerir diferenças e criatividades múltiplas, muito mais que padronizações e repetições.

\section{REFERÊNCIAS}

BECKER, B. K. Amazônia. São Paulo: Ática, 1990a. (Série Princípios)

CORREIO DO TOCANTINS, Marabá, 01.01.2004 a 04.01.2004, Cad. Cidade, p. 01.

CORRÊA, R. L. A periodização da rede urbana da Amazônia. Revista Brasileira de Geografia, Rio de Janeiro, v. 49, n. 3, p. 39-68, jul./set. 1987.

CORRÊEA, R. L. O espaço urbano. 4. ed. São Paulo: Ática, 1999.

DIAS, C. V. Marabá - centro comercial da castanha. Revista Brasileira de Geografia, Rio de Janeiro, v. 20, n. 4, p. 45-89, out./dez. 1958.

EMMI, M. F. A oligarquia do Tocantins e o domínio dos castanhais. 2. ed. Belém: UFPA/NAEA, 1999.

LEFEBVRE, H. Espaço e política. Belo Horizonte: UFMG, 2008. 
A revolução urbana. Belo Horizonte: UFMG, 2002.

O direito à cidade. 5. ed. São Paulo: Centauro, 2001.

LIMA, M. de M. Interfaces da cidade com o rio no Sudeste Paraense: estudo sobre a orla fluvial de Marabá. 2010. [s.n]. Relatório de Pesquisa (Programa Institucional de Bolsas de Iniciação Científica). Pró-Reitoria de Pesquisa e Pósgraduação, Universidade Federal do Pará, Belém: UFPA, 2010.

MARABÁ. Prefeitura Municipal. Relatório Ambiental Urbano Integrado. Marabá, 2008.

Prefeitura Municipal. Diagnóstico do Plano Diretor de Marabá. Marabá, 2006.

MARABÁ. Secretaria do Estado de Desenvolvimento Urbano e Regional. Projeto de melhoria urbana do bairro do "Cabelo Seco" Marabá - PA. Marabá, 2007.

MOURA, I. B. De Belém a São João do Araguaia: Vale do Tocantins. Belém: SECULT/Fundação Tancredo Neves, 1989.

NASSER, A. C. A; FUMAGALLI, M. A opressão da equivalência, as diferenças. In: MARTINS, J. de S. (Org.). Henri Lefebvre e o retorno à dialética. São Paulo: Hucitec, 1996. p. 25-37.

SANTOS, Milton. A natureza do espaço: técnica e tempo, razão e emoção. 4. ed. São Paulo: Hucitec, 2009.

O espaço dividido: os dois circuitos da economia dos países subdesenvolvidos. 2. ed. São Paulo: USP, 2008.

O espaço do cidadão. 7. ed. São Paulo: EDUSP, 2007.

Técnica, espaço, tempo: globalização e meio técnico-científico informacional. São Paulo: Hucitec, 1994. (Col. Geografia: Teoria e Realidade, 25). SILVA, M. A. P; MALHEIRO, Bruno C. P. Faces ribeirinhas da orla fluvial de Belém: espaços de (sobre)vivência na diferença. In: TRINDADE JR, S.-C. C.; SILVA, Marcos Alexandre Pimentel (Orgs.). Belém: a cidade e o rio na Amazônia. Belém: UFPA, 2005. p.145-169.

TRINDADE JR., S.-C. C.; SANTOS, E. R. C.; RAVENA, Nírvia. A cidade e o rio: espaço e tempo na orla fluvial de Belém. In: TRINDADE JR, Saint-Clair Cordeiro; SILVA, Marcos Alexandre Pimentel (Orgs.). Belém: a cidade e o rio na Amazônia. Belém: UFPA, 2005. p. 12-43. 
TRINDADE JR., S.-C. C.; AMARAL, M. D. B.; SILVA, M. A. P. Das “janelas" às "portas" para os rios: compreendendo as cidades ribeirinhas na Amazônia. In: TRINDADE JR, S.-C. C.; TAVARES, M. G. da C. (Orgs.). Cidades ribeirinhas na Amazônia: mudanças e permanências. Belém: UFPA, 2008.

TRINDADE JR. S.-C. C. et al. Uma cidade média na Amazônia oriental: a centralidade urbano-regional de Marabá no sudeste paraense. Belém, 2012. No prelo

VELHO, O. G. Frentes de expansão e estrutura agrária: estudo do processo de penetração numa área da Transamazônica. Rio de Janeiro: Zahar, 1972. 